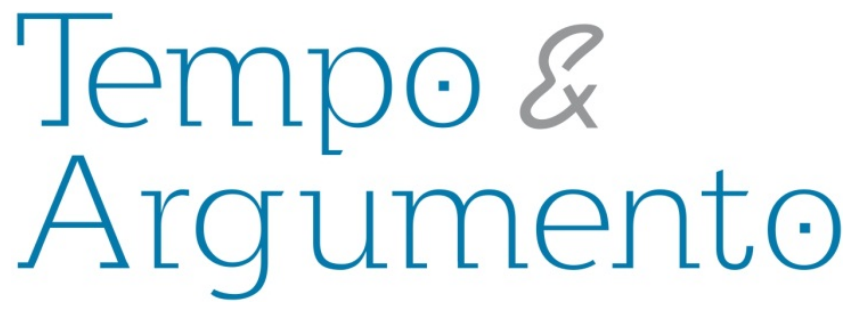

\title{
Um longo presente: O papel da imprensa no processo de redemocratização - a Folha de São Paulo em 1974
}

\begin{abstract}
Resumo
O objetivo deste artigo está em explorar possibilidades teóricas que permitam discutir a narrativa política da democratização brasileira, um processo geralmente situado a partir de 1974, quando do pretenso anúncio da distensão política por parte da ditadura militar. Uma narrativa construída pela grande imprensa, que apareceu como uma das vozes privilegiadas da democratização, estabeleceu a proeminência de determinados agentes e setores políticos e sociais. O foco do trabalho é o jornal Folha de São Paulo, em cujas páginas as negociações que envolveram o sistema político brasileiro e a valorização das eleições como forma de institucionalizar o regime, ocuparam um lugar de destaque.
\end{abstract}

Palavras-chave: Redemocratização. Ditadura. Grande Imprensa. Relações Políticas. Narrativa.

\author{
Reinaldo Lindolfo Lohn \\ Professor do Departamento de \\ História e do Programa de Pós- \\ Graduação em História da \\ Universidade do Estado de Santa \\ Catarina (UDESC). Doutor em \\ História pela Universidade Federal \\ do Rio Grande do Sul (UFRGS) \\ reilohn@hotmail.com
}

\footnotetext{
Para citar este artigo:

LOHN, Reinaldo Lindolfo. Um longo presente: O papel da imprensa no processo de redemocratização - a Folha de São Paulo em 1974. Revista Tempo e Argumento, Florianópolis, v. 5, n.10, jul./dez. 2013. p. $72-107$.
}

\section{DOI: $10.5965 / 2175180305102013072$}

http://dx.doi.org/10.5965/2175180305102013072 


\title{
The long present: the role played by the press in the process of the Brazilian democratization - Folha de São Paulo in 1974.
}

\begin{abstract}
The purpose of this article is to explore theoretical possibilities that allow discuss the political narrative of Brazilian democratization, a process usually located from 1974, when the alleged announcement of political distension by the military dictatorship. A narrative constructed by the mainstream media, which appeared as one of the privileged voices of the democratization, established the prominence of certain agents and political and social sectors. The focus of the work is the newspaper Folha de São Paulo, in whose pages the negotiations involving the Brazilian political system and the valorization of the elections as a way to institutionalize the regime, occupied a prominent place.
\end{abstract}

Keywords: Democracy. Dictatorship. Press. Political Relations. Narrative.

\section{O tempo da transição}

Em 05 de Outubro de 1988, quando o Deputado Federal Ulysses Guimarães, na condição de Presidente da Assembleia Nacional Constituinte, declarou promulgada a então chamada "Constituição cidadã", fez questão de afirmar: "temos ódio à ditadura. Ódio e nojo". No mesmo dia, o jornal Folha de São Paulo destacou: "Nova constituição entra em vigor; termina a transição para a democracia". A manchete era acompanhada da informação de que o governo do Presidente José Sarney aproveitara os últimos 

texto constitucional, o Congresso Constituinte, eleito em 1986, confirmaria algumas demandas populares que tomaram o espaço público nos anos precedentes e frustraria muitas outras.

A maior das frustrações seria o domínio do Congresso Constituinte por um grupo majoritário, o chamado "centrão", composto principalmente por parlamentares do Partido do Movimento Democrático Brasileiro (PMDB), estrutura que perdera boa parte de sua coesão interna ao receber inúmeras adesões de políticos pouco comprometidos com os esforços para estabelecer um modelo político democrático, juntamente com seus congêneres do Partido da Frente Liberal (PFL), composto por antigos apoiadores da ditadura (PILATTI, 2008, p.1-18). Tornaram-se generalizadas as práticas de negociação direta com o Executivo, o que ficou nítido na definição do mandato de cinco anos para o Presidente Sarney. A lógica da conciliação e da postergação de decisões, para obter melhores resultados nos acordos políticos pretendidos, presidiu os trabalhos. Foi o prenúncio de práticas parlamentares que se aprofundariam desde então nas relações entre Executivo e Legislativo. Foram mantidos os acordos e os limites impostos pela negociação que ocorreu ao longo final do regime militar: a manutenção da anistia para os que perpetraram a ditadura e suas violências, a insubmissão das Forças Armadas à ordem democrática mais ampla, os privilégios de categorias e instituições no interior do aparelho de Estado, as dificuldades impostas às reformas sociais, entre outros.

O objeto deste artigo está na exploração de possibilidades teóricas que permitam abordar historicamente a narrativa política da redemocratização brasileira, processo situado frequentemente a partir de 1974. Ao definir, na década de 1980, o período que então se encerrava como uma transição, o jornal Folha de São Paulo não lançava mão de uma análise posterior, em perspectiva temporal. A longa transição brasileira teve marcos definidores que o próprio jogo político do regime autoritário delimitou e foram tacitamente aceitos pelos que participaram, direta ou indiretamente, das negociações que redundariam no fim do regime autoritário. Afastar qualquer possibilidade de ruptura 

que, ao longo das décadas de 1970 e 1980, assumiu uma importância social inovadora no Brasil, tanto pelas mudanças tecnológicas, então ocorridas no campo das comunicações, quanto pelas configurações da sociedade brasileira, que passou por um processo de urbanização acelerado, com destaque para as camadas médias no conjunto da população. A grande imprensa empresarial, na condição de cronista e elaboradora dos registros políticos de então, contribuiu para a definição de marcos temporais, além de sublinhar interlocutores e analistas do processo, por meio de um agenciamento narrativo junto à chamada oposição liberal consentida e, mesmo, aos governantes que, embora sob um regime autoritário, buscaram legitimidade social. Aquele foi ainda um largo período no qual a sociedade brasileira assistiu a transformações em várias dimensões, com a urbanização e a afluência de camadas médias portadoras de estilos de vida pautados em bens de consumo modernos.

A mediação entre os agentes políticos e o público de leitores envolveu a construção de um repertório interpretativo que acentuou o protagonismo de determinados agentes sociais e políticos, num processo de elaboração de uma memória histórica sobre a democratização brasileira e a superação da ditadura civil-militar, autodenominada "Revolução", que dominava o país desde 1964. Este repertório envolveu a difusão de uma terminologia política que alcançou valor simbólico ao longo do período e que alimentou os oponentes ao regime: democracia, voto, justiça eleitoral, cidadania, direitos, liberdade de imprensa, entre outros. Outro tipo de terminologia tendeu a perder espaço, tanto o associado à esquerda, como revolução, vanguarda combativa, luta direta e armada, quanto aquele vinculado à direita: ordem, hierarquia, autoridade ou conservação.

A transição, assim montada, procurou limitar o processo de democratização brasileiro às disputas eleitorais e aos mecanismos institucionais derivados dos acordos conduzidos entre o governo, representado politicamente pela ARENA (Aliança Renovadora Nacional — posteriormente, PDS: Partido Democrático Social) e a maior 

apresenta-se como uma das instâncias organizadoras do social e, ao narrar e atribuir significados, angaria legitimidade como uma das estruturas definidoras do que deve ser lembrado ou esquecido.

Há uma renovada discussão acerca das interpretações predominantes sobre a transição para um sistema político democrático no Brasil, até aqui concentrados basicamente em torno de três eixos: o retorno aos valores liberais-democráticas que estariam em disputa no momento do golpe civil-militar de 1964; a ruptura com o autoritarismo que marcara o regime, como um contraponto aos seus relativos êxitos econômicos; por fim, o pacto que se teria sido firmado entre governo e oposição, com a atuação de um amplo conjunto de forças sociais (ABREU; LATMAN-WELTMAN, 2006, p. 69). Ressalta-se que uma das marcas dessas interpretações é a indefinição de datas precisas, embora os debates políticos que se travou tenha elaborado marcos que se tornaram aceitos: um destes é 1974. Neste trabalho, pretende-se explorar as tramas narrativas que foram articuladas naquele ano, no interior das páginas do jornal Folha de São Paulo.

No conjunto de personagens, individuais e coletivos, que tomaram parte no processo social que envolveu o fim da ditadura, a proeminência da narrativa da redemocratização coube à imprensa. Ao longo do processo, esta compreensão foi compartilhada pelos personagens principais, que passaram a ter um espaço que virtualizou, em pleno regime autoritário, um momento em que governo e oposição estabeleceram um diálogo público. A estes foi dedicado espaço, matérias investigativas, informações de bastidores e farta análise. Constituía-se, assim, a elaboração de uma explicação histórica, no momento mesmo da ocorrência dos eventos, que conduziria a uma interpretação consensual da redemocratização brasileira. Uma determinada ordenação narrativa apontou os rumos e praticamente estabeleceu, em conjunto com os interlocutores políticos, um calendário que organizaria a aceitação de práticas democráticas no país: as eleições passaram a significar a própria democracia. Votar 
tornou-se o alvo a ser perseguido para a definição de um regime democrático. Algo que, à primeira vista, pode parecer obvio. No entanto, sabe-se que há muitas definições de democracia e sua prática constitui um exercício elaborado e sua complexidade não se esgota em mecanismos institucionais.

Diante da tarefa de atuar no âmbito de um regime autoritário e a construir a aceitação de resultados eleitorais favoráveis a uma oposição consentida, cuja existência deveria limitar-se a atribuir legitimidade para um jogo político que não ameaçasse a ordem prevista, coube reduzir ao máximo o alcance das possíveis demandas advindas de um processo de democratização e restringi-lo a determinados momentos. Associar democracia, tão só, a eleições regulares para todos os níveis do Executivo e do Legislativo, foi uma operação a que se dedicaram governo e oposição dedicaram-se e seus tramados podem ser detectados nas páginas dos jornais. No caso deste trabalho, a Folha de São Paulo foi um órgão de imprensa que chegou a quase confundir-se com determinados momentos da redemocratização, embora, nos primeiros anos do processo, não fosse possível detectar a que ponto isso chegaria. Cabe referir-se aqui ao ano de 1984, quando o jornal encampou a defesa das eleições diretas para a Presidência da República e foi um dos personagens relevantes da campanha das “Diretas Já!”. Tomar a Folha como documento envolve, portanto, considerar que o próprio jornal assumiu feições e posturas advindas da própria transição que registrou e definiu em suas páginas: reinventou-se ao longo do processo.

\section{A presença do passado}

Cabe considerar a dimensão temporal do processo de redemocratização brasileiro. Entre um ponto inicial e outro final, ocorreu um período intermediário no qual seriam verificadas mutações, descontinuidades e continuidades. O espaço de tempo intermediário foi tão longo, cerca de dez anos, que a estrutura temporal elaborada afirmaria um longo presente e sua trama foi encetada, entre outros agentes, pela narrativa jornalística. Entender-se como parte daquele presente alargado, significou situar-se em um ponto de um ciclo, o que garantiria certa homogeneidade ao que seria, 

apresenta-se como "um modo particular de um processo genérico e elementar do pensamento humano". Ao desenvolver uma consciência sobre o tempo e ao agir intencionalmente, o homem interpreta o mundo. Esta operação ocorre "sempre de modo todo especial quando os homens têm de dar conta das mudanças temporais de si e do mundo mediante seu agir e sofrer" e, assim, é formado "um quadro interpretativo" das experiências em mudança no tempo. De sua parte, os meios de comunicações e as mídias jornalísticas operam "tessituras nas quais passado, presente e futuro são constantemente mobilizados em atitudes que se situam fora do campo da história e que se materializam em um tipo particular de escrita" (SILVA, 2011, p. 13-14). Diante disso, pode-se entender que a narrativa realizada pela imprensa daquele longo presente resultou num agenciamento sobre o tempo e, por extensão, o conhecimento históricos.

Diferentes processos ocorridos em países latino-americanos nos quais houve a passagem de regimes autoritários para formas democráticas ao longo da década de 1980 foram qualificados como transições, numa tentativa de detectar suas semelhanças. Uma literatura dedicada ao tema foi bastante profícua desde então, como aponta Adriano Nervo Codato (2005, p. 83-106). Este mesmo autor aponta que os atores envolvidos no processo foram divididos, basicamente, em três grandes grupos em processo evolutivo de mudança no período considerado: Forças Armadas, Estado e Sociedade. A construção de uma normativa institucional liberal democrática no Brasil esteve pautada pelas características de uma longa negociação, na qual os militares não transferiram todo o poder a seus apoiadores civis, tampouco submeteram-se a seus opositores moderados. A criação da Frente Liberal, em 1984, que arregimentou antigos próceres civis do regime para apoiar a candidatura do oposicionista Tancredo Neves no Colégio Eleitoral, ilustra o quanto foi possível que aquele período de tempo não fosse apenas um ponto intermediário: foi o próprio objeto da negociação, que deveria ser tão longa quanto fosse necessário arranjar o jogo político de tal maneira que afastasse rupturas. Isso quer dizer que ao longo do processo não estava estabelecido um momento final de antemão, "a 

lenta, segura e gradual - da forma de governo." Assim, o momento posterior e final, não corresponde a um encerramento do que foi iniciado antes, nem difere fundamentalmente do que havia no começo do processo.

A compatibilização de diferentes variáveis e elementos que se conjugaram para a aceitação de um modelo de organização do poder, no qual a representação política é antes uma defesa do Estado contra iniciativas populares, na forma de uma democracia tutelada em que a sociedade encontra canais restritos de participação, contou com a interveniência de setores que adquiriram legitimidade social ao longo do processo. Na medida em que o sistema político apontava para uma democratização relativa de seus procedimentos e componentes, a imprensa apresentou-se como espécie de porta-voz da sociedade em relação ao Estado, aos políticos e às próprias Forças Armadas. Apesar da diversidade e do grande número de órgãos de imprensa existentes, Flávia Biroli (2009, p. 269-291) pontua que, desde antes do golpe de 1964, ao longo do regime constitucional de 1946, houve a tendência a certa homogeneidade de posicionamentos por parte dos grandes jornais brasileiros, em geral antigetulistas e contrários aos projetos nacionalistas de reformas sociais do início da década de 1960. Em que pese o apoio ao golpe e as ambiguidades em relação ao regime autoritário, os órgãos de maior destaque e influência trataram de construir uma representação homogênea sobre o processo de redemocratização e assegurar um papel central aos jornalistas como atores indispensáveis da recusa à censura. A defesa da liberdade de imprensa como dimensão mais importante de liberdade de expressão, preencheu as lacunas e omissões dos períodos de apoio explícito ao regime autoritário como meros equívocos, para acentuar o protagonismo da imprensa na construção da democracia. Assim, coube à imprensa pontuar o momento final da transição, quando esta cedeu lugar a um novo quadro que significaria a superação do passado. Neste caso, há um esforço por identificar "a existência de uma ruptura entre passado e presente". Os erros, os equívocos teriam ficado em um “passado encerrado". Nesta acepção está localizada “a possibilidade de se 
período apoiou e sustentou o regime militar, aparecer como uma das vozes privilegiadas da democratização e construtora de uma narrativa histórica que consagrou a vitória de agentes e setores políticos e sociais. Nas páginas dos jornais, ao longo da segunda metade da década de 1970, a política voltou a ocupar um espaço de destaque e as relações verticais de um regime ditatorial, que hierarquizou Forças Armadas, Estado e Sociedade, puderam ser expressas de maneira horizontal no debate entre governo e oposição. Cabe, assim, compreender como a redemocratização passou a ser apresentada como uma estrutura linear que configurou passado, presente e futuro como momentos distintos e fechados em si. Se é possível compreender a política como um lugar nodal, um ponto de congruência no qual se pode perceber a articulação entre o social e suas representações, ao permitir que numa mesma empreitada sejam enfrentadas as tarefas que envolvem tanto a compreensão do passado quanto a interrogação do presente (ROSANVALLON, 1995, p. 12-19), então é necessário seguir alguns dos fios desses nós de possibilidades que tenderam a constituir uma até então improvável arena de discussões públicas, ainda que limitada ao sistema partidário, no interior de jornais que seguiram comprometidos com a estrutura de poder vigente.

A Folha até então, não fora um ator de peso no conjunto da imprensa brasileira. Fundada em 1921, a empresa jornalística estreou com a Folha da Noite e, quatro anos mais tarde, apresentou a Folha da Manhã. Em 1949 houve a criação da Folha da Tarde. A unificação dos jornais sob o título Folha de São Paulo ocorreu no início de 1960. Depois de diversas fases e configurações diferentes de proprietários e diretores, a empresa passou ao comando definitivo de Octávio Frias de Oliveira em 1962. Em 1967 a Folha da Tarde voltaria a circular e, depois de um período de relativa diversidade na cobertura, logo passaria a ser um dos principais órgãos de imprensa a contribuir com o aparato repressivo da ditadura militar (KUSHNIR, 2005, p. 315). Em paralelo, inovações administrativas e tecnológicas aumentaram a participação da Folha de São Paulo no mercado, o que logo redundaria em maior influência editorial junto ao público, principalmente nos anos de 
1970 sob o comando de Cláudio Abramo na redação. A partir daí, o jornal ganhou prestígio e capacidade para participar do processo político em curso. As ambiguidades de um jornal que se pretendia liberal, mas que praticava a autocensura na redação, são parte da trajetória da grande imprensa brasileira e suas relações privilegiadas com o poder político e as redes empresariais. No relato mais comum de sua História, a Folha registra que "não agradava a gregos nem a troianos", quando teve dois veículos de sua frota queimados por militantes de grupos clandestinos de resistência à ditadura (MOTA; CAPELATO, 1981, p. 200-208).

A imprensa foi, então, parte indispensável do tramado narrativo que organizou a temporalidade e permitiu construir uma periodização que se apresentou como autoevidente, com um calendário e um roteiro do teatro político. A trajetória de um ciclo narrativo não pressupõe apenas um encadeamento linear de sucessões e transformações, tampouco é composta por uma situação inicial estável da qual advém um equilíbrio final, como se afirmasse a completude de um tempo unificado, conforme a perspectiva de Tzvetan Todorov (1970, p. 137; 179) acerca da narrativa literária. Nem presente perpétuo e nem eterno retorno, mas uma conjunção de temporalidades por meio do "agenciamento dos fatos", para o qual concorrem, segundo Paul Ricoeur (1994, p. 25-26; 63), as intencionalidades dos atores que tecem a trama narrativa e reúnem incidentes e fragmentos, por vezes discordantes, numa cadeia de eventos ordenados e discerníveis, com a qual se habilitam a perceber-se neste ciclo narrativo e mesmo prever movimentos futuros. Por meio desta tessitura do tempo histórico, "narramos as coisas que consideramos verdadeiras e predizemos acontecimentos que ocorrem tal como havíamos antecipado".

A imprensa escrita apareceu não apenas como espectadora, mas como interlocutora nas questões políticas que envolveram a chamada "distensão", ponto nodal das relações que seriam articuladoras da posterior "Nova República”. As páginas dos jornais, aos poucos, constituíram-se em veículos para as representações sociais e políticas do país como um todo, a ponto de setores da imprensa situarem-se como peças indispensáveis da construção democrática brasileira. Para Alzira Alves de Abreu e Fernando Lattman-Weltman (2006, p. 76), a crescente rejeição à censura criaria 

parte do governo Geisel, nas páginas da Folha de São Paulo.

\section{4: lento e gradual}

A Folha de São Paulo do dia 26 de janeiro de 1984 estampou em sua primeira página: "300 mil nas ruas pelas diretas". A foto panorâmica de uma multidão na Praça da Sé, sob a torre da Catedral, no centro de São Paulo, maior núcleo urbano do país, ilustrou um texto que, após citar as lideranças políticas envolvidas no movimento das "Diretas Já!”, tais como Luís Inácio Lula da Silva e Ulisses Guimarães, pontuou que “o verdadeiro herói foi outro: a multidão, as 300 mil pessoas que provaram ser possível (e desejável) fazer política com amor, garra e alegria" (FOLHA DE SÃO PAULO, 26/01/1984, p. 1). O comício de janeiro de 1984 foi o maior até então de uma série de eventos similares ocorridos desde o ano anterior, com a conjunção de esforços dos partidos de oposição ao chamado regime militar. A redemocratização do sistema político brasileiro pareceu estar muito próxima naqueles meses. A campanha pelas diretas é tanto um símbolo como o auge de um processo mais amplo de constituição de novas culturas políticas e de linguagens públicas criadas no momento da crise da ditadura militar. Para Serge Bernstein (1998, p. 352-353), "a cultura política, como a própria cultura, se inscreve no quadro das normas e dos valores que determinam a representação que uma sociedade faz de si mesma, do seu passado, do seu futuro". É nesse quadro que se entende a possibilidade de localizar as balizas que tornaram possível o consenso sobre o que deveria ser considerado parte da chamada transição democrática e o que deveria ser deixado para trás, no passado.

Não havia muita dúvida sobre o que esquecer. O mesmo jornal, no dia 20 de março de 1964, saudou a manifestação que se formou na mesma Praça da Sé para celebrar a denominada "Marcha da Família com Deus e pela Liberdade". O título da principal notícia, sobreposto a fotos da multidão, anunciou: "São Paulo parou ontem para defender o 
objetivo da mobilização: "a multidão que lotou a praça da Sé manifestou-se abertamente contra o governo". Cartazes exigiam o "impeachment” de João Goulart e denunciavam os "traidores da pátria". Como resposta ao comício ocorrido em 13 de março, no Rio de Janeiro, de apoio ao governo João Goulart, a Folha de São Paulo opinou que a manifestação paulista fora uma reunião espontânea do "povo mesmo, não um ajuntamento suspeito" (FOLHA DE SÃO PAULO, 20/03/1964, p.1).

Entre as multidões de 1964 e as de 1984, no centro de São Paulo e de outras capitais brasileiras, bem como entre as manchetes de jornais e revistas separadas por vinte anos, processos sociais de diversas ordens marcaram a população brasileira e constituíram fios de uma tessitura social com a qual os significados políticos foram construídos. Novos fenômenos ligados à emergência da cultura de massa e a importância cada vez maior das classes médias enquanto consumidoras de bens simbólicos, bem como interessadas na leitura de jornais e revistas, contribuíram para moldar novas expectativas em relação à participação política. O aumento do número de universitários e a ampliação dos meios de comunicação de massa, fenômenos associados principalmente à urbanização, impuseram inflexões a uma sociedade brasileira em mudança. As mídias sofreram intensas mudanças tecnológicas, profissionais e de escala de cobertura durante o regime ditatorial. Ao processo de profissionalização, perceptível a partir da década de 1950, somou-se, na década de 1970, uma intensa concentração empresarial e de poder político em alguns veículos. O progressivo deslocamento das verbas publicitárias para a televisão tornou o mercado de jornais e revistas inviável para um bom número de empresas. A venda avulsa não mais garantiu a sobrevivência de muitos títulos e as receitas publicitárias passaram a ser indispensáveis. A industrialização dos processos de produção favoreceu os grandes grupos empresariais, únicos capazes de arcar com os investimentos necessários. Assim, há a consolidação de um mercado de grandes jornais e revistas em torno de alguns poucos títulos, concentrado no eixo Rio de Janeiro e São Paulo. Enquanto os que se aproximaram do regime tiveram enormes ganhos, como o 
grupo Globo, os mais recalcitrantes foram inviabilizados, caso da Última Hora. Escudados nas novas técnicas que padronizaram a linguagem jornalística, os grandes veículos puderam passar a oferecer uma mercadoria que primava pela qualidade técnica da apresentação e com conteúdo voltado a não criar problemas com o mercado e, principalmente, com o governo (RIBEIRO, 2006, p. 428-430).

Pelos meios de comunicação, nas sociedades contemporâneas, "o acontecimento marca sua presença”. Para Pierre Nora (1988. p. 181-188), "as afinidades entre tal tipo de acontecimento e tal meio de comunicação são tão intensas que eles nos parecem inseparáveis". Além disso, a redundância intrínseca aos mass media tenderia "a produzir o sensacional", a fabricar "permanentemente o novo" e a alimentar "uma fome de acontecimentos", o que impõe "imediatamente o vivido como História”. A promoção do “imediato ao histórico" ocorreu com mudanças no próprio estatuto do acontecimento: "sobre qualquer acontecimento no sentido moderno do termo, o imaginário de massa quer poder enxertar qualquer coisa do fato cotidiano". De outra parte, os acontecimentos políticos tradicionais passaram a dotar-se de tais características e conjugar-se a uma "teatralidade" imposta pelas novas formas de apreensão do vivido e do imediato, dotados de condição histórica. Para sua decifração, cabe atentar para o que tem de menos arbitrário em seus desdobramentos, ou seja, "seu surgimento, seu volume, seu ritmo, seus encadeamentos, seu lugar relativo, suas sequelas e seus saltos obedecem a regularidades". Um agenciamento ordenador dos acontecimentos ocorre por meio da elaboração constante de discursos narrativos que produzem efeitos de real e são geradores de significado. Um de seus fatores distintivos está na condição "preditiva" de que são capazes, ao operarem as narrativas contemporâneas. Segundo Roland Barthes (1972 p. 35-44), o discurso narrativo prediz: "se você agir de tal maneira, se você escolher tal alternativa, eis o que vai obter". Há então um conjunto de prescrições implícito em instruções e normas que servem como guias para a atribuição de sentido às experiências sociais de coletividades e indivíduos.

O acontecimento que interessa a este trabalho foi o que teria sido o anúncio, por parte do General Ernesto Geisel, então Presidente da República e responsável pela condução do regime ditatorial, da chamada distensão em 1974. Numa reunião com 

seria um abrandamento do regime, a fala presidencial parecia pouco aberta à negociação. Após acentuar a necessidade do partido oficial promover uma "eficiente motivação política do povo brasileiro" e exaltar as qualidades do sistema bipartidário, o tom foi o de uma advertência: frisou que não aceitaria "pressões indevidas" dos que pensavam "poder apressar" alterações no regime por meio de um "jogo de pressões manipuladas sobre a opinião pública e, através desta, contra o governo". Tais pressões apenas serviriam para "provocar contrapressões de igual ou maior intensidade, invertendo-se o processo de lenta, gradual e segura distensão, tal como se requer", o que geraria um clima de "crescente polarização e radicalização intransigente, com apelo à irracionalidade emocional e à violência destruidora". Também acentuou que realizava um "pronunciamento oficial esclarecedor" diante de diferentes manifestações "sobre o momento político brasileiro, largamente difundidas e comentadas pela imprensa". O governo aceitava debates e discussões sobre a "problemática política" para a “institucionalização do ideário da Revolução de 64", mas repeliu “campanhas reivindicadoras" que pretendessem "forçar mudanças e revisões inconvenientes, prematuras ou imprudentes do quadro político nacional". Alertou ainda que o regime permanecia atento às "minorias subversivas", contra as quais os "órgãos de segurança” permaneceriam atuantes, rigorosos e duros, "mas sem excessos condenáveis" e “violências inúteis". (FOLHA DE SÃO PAULO, 30/08/1974, p. 1).

Desta manifestação de Geisel, destacam-se ao menos duas questões relevantes para este trabalho: a definição de uma temporalidade para o processo que seria o da institucionalização do regime (e não o de uma transição democrática) e o reconhecimento da interlocução com setores políticos por meio da imprensa e da opinião pública. Chamado a negociar, o governo apresentou suas condições, das quais, como várias análises posteriores demonstraram, pouco abriria mão. O ritmo seria ditado pelo regime, bem como a forma: a institucionalização envolveria interlocutores aceitos entre aqueles com acesso a um espaço público que teria a imprensa como baliza. A Folha 

os cientistas políticos, a "normalidade institucional” seria alcançada "progressivamente, por degraus". A ARENA acatou as invectivas do General-Presidente como "uma voz de comando" de seu líder, conforme o Senador Jarbas Passarinho, enquanto o MDB, por meio do Deputado Tales Ramalho, recusou-se a comentar pontos específicos da fala, mas acentuou que o "sistema bonapartista brasileiro" era artificial por restringir o número de agremiações políticas, o que faria a "revolução afastar-se do seu ideário original, exposto pelo Marechal Castelo Branco: a busca da normalidade institucional" (FOLHA DE SÃO PAULO, 30/08/1974, p. 3).

Nos dias seguintes, os interlocutores políticos prosseguiram as avaliações do pronunciamento, nas quais os dirigentes da ARENA chamaram a atenção para a unidade partidária com vistas às eleições daquele ano. O Senador Nelson Carneiro, do MDB, por sua vez, pontuou que o próprio partido oficial, dividido em sublegendas, contrariava o bipartidarismo defendido por Geisel e que a distensão apresentava-se "cautelosamente remota". Pertencente ao mesmo partido, o Deputado Lisâneas Maciel considerou que, apesar de incentivar a participação política popular, a cautela pretendida impedia a “normalidade democrática” (FOLHA DE SÃO PAULO, 31/08/1974, p. 3). Alguns outros arenistas acreditaram tratar-se de um passo "em direção da plena redemocratização do país", enquanto outros sublinharam a definição dos "parâmetros prudentes para a travessia da conjuntura", com a manutenção da "Revolução" e da vigência das "regras do jogo" (FOLHA DE SÃO PAULO, 01/09/1974, p. 3).

Esse emaranhado de falas de governistas e oposicionistas, além de contribuições de analistas, percebe-se um agenciamento no interior das páginas do jornal, no sentido de organizar uma narrativa que viesse a interpretar o fato e demarcá-lo em suas características de acontecimento político cujos desdobramentos pudessem ser inteligíveis. No jogo de posicionamentos, é possível compreender a construção de um espaço político delimitado. Nessa arena restrita, as possibilidades de negociação começaram a ser experimentadas. Para Leonardo Avritzer, a negociação política 

atribuído pelos atores políticos à democracia", o que redundaria em "diferentes concepções acerca da publicidade, da tolerância, da importância de estratégias de negociação e da importância da normatividade democrática". O autor pontua que, no processo de negociação, “uma cultura política não-democrática” pode entrelaçar-se com “a institucionalidade democrática”, ou seja, “as práticas dominantes, neste caso, não são puramente democráticas nem puramente autoritárias" (AVRITZER, 1995). No conjunto de elementos que faziam parte daquele processo, a imprensa atuou como uma das fornecedoras de um repertório social capaz de tornar inteligíveis os termos da negociação, o que a tornava parte do aprendizado em curso. A negociação seria compreendida como um processo de aceitação das regras para a institucionalização do regime, por meio de eleições regulares.

No exercício da Presidência, conforme seu próprio depoimento, Geisel "recebia uma súmula dos principais assuntos tratados pela imprensa. Lia aquilo, passava os olhos em algum jornal e ia para o Planalto". Evitava as entrevistas e afirmou que "não dava muita importância à imprensa". Suas considerações sobre os jornais são reveladoras: “construir com ideias ou cooperar é muito raro. O jornal precisa ter essas notícias para ser lido e vendido, para ter tiragem, receber anúncios e assim ganhar dinheiro" (D'ARAÚJO; CASTRO, 1997, p. 276-286). Os organizadores do "Dossiê Geisel", com parte do acervo documental deixado pelo General-Presidente, avaliaram que apesar de sua vinculação ao processo de abertura política, “a imagem do governo Geisel que sai desses papéis é a que enfatiza o controle político, a repressão à esquerda e à oposição, e a censura à imprensa", o que diferia da imagem que foi fixada pelos órgãos de imprensa, que “mostra um Brasil mais aberto". Manteve-se uma clara preocupação em controlar a imprensa do centro do país, na qual haveria "infiltração comunista", além do "dilema das empresas jornalísticas em querer fazer seu negócio ser rentável sem desagradar ao governo" (CASTRO; D’ARAÚJO, 2002, p. 23-30). 
No início de 1974, ao avaliar os possíveis efeitos da crise do petróleo sobre a economia brasileira, em editorial a Folha de São Paulo pontuara que "a Revolução implantou um processo que, evoluindo lentamente, só comporta alterações graduais, insuscetíveis de produzir efeitos a curto prazo". O jornal apostava que o "quadro políticoinstitucional” não sofreria mudanças com “repercussão imediata”. Àquela altura, o que se poderia esperar era tão somente a "democracia das oportunidades" para, então, lançar "as bases de uma nova e adequada estrutura institucional, a qual nada tem a ver com os regimes do passado pré-revolucionário" e compreender que "o esforço de cada um na construção do futuro haverá de antecipar o resultado da recompensa devida" (FOLHA DE SÃO PAULO, 01/01/1974, p. 3). Estava claro que o gradualismo de medidas propícias a mudanças não estava restrito às intenções do governo. A passagem lenta e gradual, correspondia aos agenciamentos narrativos que ordenariam as relações políticas, tanto do governo quanto da oposição e da própria imprensa. O presente é avaliado à luz de certa consciência histórica que tem como baliza negativa o passado anterior a 1964 e lança para um futuro, mais ou menos indeterminado, os frutos da parcimoniosa alteração no quadro institucional. Há a definição de uma estrutura temporal que mobiliza uma memória social e inscreve-se no horizonte político.

Entre o golpe de 1964 e a campanha pelas diretas em 1984, o ano de 1974 constituiu-se uma passagem no tempo, a unir os fios que levam de um extremo a outro do período. Em Janeiro, um nota do jornal Folha de São Paulo chamava a atenção para as dificuldades do MDB: “oposição na hora da verdade”. As eleições daquele ano significariam um questionamento sobre "o real poder do partido, e que será revelado, inexoravelmente, nas urnas" (FOLHA DE SÃO PAULO, 10/01/1974, p. 4). O quadro, de fato, não parecia animador para uma oposição limitada e consentida, que tentava contrapor argumentos a um governo autoritário e que tinha a seu favor um período de crescimento econômico acelerado. O General Presidente, Emílio Garrastazu Médici, que comandou o período de maior atuação das forças de repressão da ditadura, podia afirmar que seu período de governo fora marcado pela eficiência de uma política econômica que, “conduzida com objetividade e firmeza, transformou a fisionomia econômica do país, cuja 
como uma experiência da sociedade brasileira e uma narrativa coletiva que ordenou as ações dos agentes políticos. O discurso jornalístico ocupou nas sociedades contemporâneas "o papel institucional de produzir sentidos passíveis de inscrição na memória social", daí a necessidade de examinar "de que modo vem a instituir-se e a produzir os efeitos de verdade e consenso que muitas vezes acabam por orientar nossas ações e nosso pensar" (FERREIRA, 2007, p. 58). Aquele ano seria considerado a baliza demarcatória inicial da chamada transição. Como elemento objetivo, cabe considerar que, apesar do regime autoritário e do cerceamento das mobilizações públicas, houve uma renovada importância para os processos eleitorais a partir de 1974, quando o MDB obteve uma vitória emblemática (LAMOUNIER, 1988). De certo modo, em resposta ao regime e à supressão de liberdades próprias da cidadania (civil, política e social), os processos eleitorais apareceram não mais apenas como mecanismos formais de uma democracia de fachada, mas como meios de expressão consciente da população e de elaboração de uma cultura política democrática. A política de massas e o voto popular foram reabilitados, pois mesmo o partido oficial do regime militar, a ARENA, viu-se na necessidade de moldar sua atuação em função das pressões eleitorais (GRINBERG, 2009).

As narrativas do processo político brasileiro daqueles anos, operadas por meio da imprensa, demarcaram o início de um ciclo que corresponderia à redemocratização, embora não fosse claro qual sua forma. O predomínio das Forças Armadas na ordenação do regime continuamente aparecia como limite do possível. O chefe do Estado-Maior do Exército, General Dale Coutinho, afirmava que o país vivia "uma guerra revolucionária, estimulada pelo movimento comunista internacional nos meios urbano e rural" e que a “Revolução de março de 1964" deveria ser garantida "a qualquer preço" (FOLHA DE SÃO PAULO, 04/01/1974, p. 4). Na hierarquia da ditadura, não restava dúvida até que ponto poderia funcionar o sistema político. Os militares faziam questão de determinar sua proeminência na condução do Estado e na gestão da sociedade. Quanto aos civis, cabia a expectativa pelo pronunciamento do General Geisel no ato de sua "eleição" por meio de 
um Colégio Eleitoral. O Senador Petrônio Portela, então presidente da ARENA, ao ser questionado sobre um possível discurso "muito duro", por parte do presidente do MDB na ocasião, relativizou: "pouco importa que a fala de Ulysses seja dura ou mole, pois é coisa deles, do MDB" (FOLHA DE SÃO PAULO, 09/01/1974, p. 3). Na divisão de poderes do regime, na qual os militares assumiam o comando do Estado, um espaço de discussão horizontalizada entre civis governistas e oposicionistas parecia virtualmente possível na crônica política da imprensa. Na retórica oficial, o ritual que envolvia uma eleição de resultado absolutamente previsível no Colégio Eleitoral, significava "a valorização do Poder Legislativo" e a demonstração da "grandeza da classe política, na hora presente" (FOLHA DE SÃO PAULO, 10/01/1974, p. 3).

O líder do MDB, Ulysses Guimarães, que havia lançado sua chamada “anticandidatura" à Presidência no ano anterior com a "finalidade de contestar o processo sucessório", tendo como companheiro de chapa o jornalista Barbosa Lima Sobrinho, avaliava que sua "campanha" tivera o êxito de promover "a movimentação de ideias em torno do restabelecimento da plenitude democrática" (FOLHA DE SÃO PAULO, 12/01/1974, p. 4). A participação no pleito indireto causou uma série de controvérsias na oposição e gerou uma crise no partido, pois o chamado grupo dos "autênticos" do MDB, que rejeitava práticas conciliatórias com o regime, ameaçava não votar em Ulysses Guimarães. Enquanto a ARENA buscava legitimar o processo, pois conciliava a "ordem revolucionária com os princípios da democracia”, o candidato da oposição preocupava-se em convencer seus colegas a participarem da votação e nisso contava com parlamentares como Frederico Trota que afirmava que as eleições indiretas também eram “democráticas" e que julgava ser mais importante "lutar pela reforma constitucional, que restitua ao país o primado da lei e do princípio da liberdade com responsabilidade" (FOLHA DE SÃO PAULO, 14/01/1974, p. 4). Assim, enquanto o partido do governo referiase à “ordem revolucionária", a oposição mencionava "responsabilidade". Uma aproximação narrativa que sugeria o acatamento de parâmetros mínimos de negociação. Para a Folha, "apesar da contestação dos autênticos", Ulysses Guimarães ficaria com uma imagem, "a que a história registrará", como a de um "simpático Dom Quixote" (FOLHA DE SÃO PAULO, 15/01/1974, p. 4). Enquanto seus críticos avaliavam que nada mais queria 
candidatura, Ulysses defendeu as diversas bandeiras do programa oposicionista, entre as quais a da anistia aos "pré-condenados pelas cassações de mandatos e suspensão de direitos políticos" e a de que o único poder legítimo advém do "voto do povo". (FOLHA DE SÃO PAULO, 16/01/1974, p. 6).

Meses depois, o líder da oposição lembrou que a Revolução de 1930 fora "deflagrada para derrubar a oligarquia" que alterava os resultados eleitorais que afastavam do parlamento aqueles "que pudessem incomodar a política dos governadores", que se fazia também por meio de prisões e "assassinatos políticos". Por isso, reivindicava que fossem criadas condições para que a oposição existisse, pois “governo sem oposição vai para o porão da História" e comparava o processo político à lógica econômica de mercado, na qual "a concorrência é oposição entre as empresas, para que haja saúde econômica e proteção aos consumidores". Suas manifestações foram em resposta ao que teria sido uma declaração do Presidente Geisel que recomendara a necessidade de uma “oposição viril”. Para tanto, afirmava que a legislação eleitoral deveria limitar o número de candidatos dos partidos, cujo aumento apenas beneficiava a ARENA, pois esta precisava acomodar diferentes correntes políticas locais nos Estados, bem como rejeitar que votos nulos e brancos fossem considerados para o cálculo do quociente eleitoral, o que reduzia as chances do MDB atingir o direito a ocupar cadeiras legislativas (FOLHA DE SÃO PAULO, 27/04/1974, p. 5).

Sabe-se que a narrativa constitui o tramado necessário no qual é operada a configuração do tempo histórico, em suas diferentes manifestações e apropriações, entre o tempo vivido e o tempo da natureza, a ponto de confundi-los. O calendário, as gerações e os documentos são vivenciados e experimentados na temporalidade que reúne passado, presente e futuro. Com esta compreensão das características do tempo histórico, pode-se construir uma História do tempo presente, a qual segundo Paul Ricoeur (2007: 456) é "aquela onde esbarram uma na outra a palavra dos testemunhos ainda viva e a escrita em que já se recolhem os rastros documentários dos acontecimentos 

sociais mais abrangentes. Portanto, mover-se entre as diversas manifestações na imprensa escrita sobre a composição de um novo sistema político, abre a perspectiva para a compreensão dos horizontes de expectativas dos grupos políticos em atuação no período e da construção de uma memória histórica amplamente aceita.

Um articulista da Folha, Francisco Barreira, pontuou que o modelo político-institucional que estava em formação não possuía contornos "claramente definidos", mas apontava para "sustentar algumas características da democracia formal”, com a preservação de um "centro de decisões com instrumentos e autoridade suficientes para evitar imprevistas, intempestivas ou exageradas mudanças de rota”. Entendia que a base do governo apresentava "carência de cultura política" e que os políticos "mais argutos" deveriam buscar nas bibliotecas os "empoeirados livros de História do Brasil” para conhecer o Segundo Império, pois não seria "totalmente absurdo que expressões como poder moderador" fizessem sua "reentrada no vocabulário político". Sugeria que a conformação de uma nova estrutura de poder dependia da participação dos políticos civis, de modo que o processo ocorresse "sem maiores traumas ou retrocessos" (FOLHA DE SÃO PAULO, 29/10/1974, p. 3). Meses antes, o jornal afirmou que a eleição de Ernesto Geisel, da forma como ocorreu, mostrou que o "sistema resultante do Movimento de 1964" dera uma "prova de coesão e vigor", dado o "ambiente político estável a austero" (FOLHA DE SÃO PAULO, 17/01/1974, p. 5).

Percebe-se que a ordenação da temporalidade contemporânea por meio das narrativas jornalísticas evidencia o quanto o presente não é um lugar de passagem, mas uma lacuna e uma possibilidade inacabada entre o passado e o futuro (PEREIRA, 2009, p. 230). Os leitores da Folha de São Paulo passaram a acessar e compartilhar representações relativas a diferentes processos que se desenrolavam na sociedade brasileira, situados no período da abertura política. A frequência e a distribuição de notícias a respeito das contradições do cenário político, anseios e mobilizações, expressam a constituição de grades de leitura em comum, de modo a formar uma compreensão do que se 
desenrolava e a pluralidade de texto parecia apontar para horizontes de expectativas referenciados por meio do noticiário e das colunas de opinião. Na acepção de Reinhart Koselleck (2006, p. 305), “não há expectativa sem experiência, não há experiência sem expectativa" e o tempo histórico é constituído por tais dimensões, as quais "entrelaçam passado e futuro" e "dirigem as ações concretas no movimento social e político" que se expressão em relações e configurações assimétricas. Não demoraria para que algumas palavras-chave da redemocratização começassem a ser frequentemente mencionadas nas páginas do jornal. A afirmação de que o país começava a viver uma "abertura" do sistema político, ou ainda uma "reabertura". Indícios seriam o encaminhamento da sucessão dos governadores por meio do sistema político, sob a responsabilidade do Senador Petrônio Portela, e não por indicações do Gabinete Presidencial, além da afirmação do então Deputado Tancredo Neves de que estava em construção um "diálogo político" para o "entendimento nacional, visando a restauração da plenitude democrática" e das "prerrogativas do poder civil" (FOLHA DE SÃO PAULO, 13/02/1974, p. 3).

Para a Folha, contudo, o novo governo descortinava o futuro: “projetam-se agora as grandes linhas políticas e administrativas de uma Nação finalmente sedimentada e de um Estado que avança para a eficácia”. Defendia que o sabia "prever” e, portanto, “governar”. Daí que não cabia iludir-se com o que qualificou, em Editorial, como “partidocracia”, pois o "ideal futuro" seria o de "uma sociedade em hierarquia que coexista com democracia". O jornal reafirmava os mecanismos autoritários de gestão do Estado impostos pela ditadura militar e que corresponderam ao poder de uma tecnocracia que se pretendeu modernizadora e legitimada por uma suposta eficácia administrativa (PRADO; EARP, 2003, p. 207-242). Por outro lado, procurou dar a palavra ao "homem comum", por meio de entrevistas com pessoas simples, moradores da periferia de Brasília, a respeito do novo Presidente. Um deles, João de Souza, afirmou: “dizem que ele é bom, mas não sei se vai ser melhor do que o Médici, que ajudou muito o peão de obra". Na Universidade de Brasília, por outro lado, uma estudante teria perguntado à reportagem: "minha opinião vale alguma coisa?" (FOLHA DE SÃO PAULO, 15/03/1974, p. 3). 
Para a compreensão das correlações entre as expectativas acerca do processo de redemocratização localizadas nas páginas da Folha de São Paulo é necessário um trabalho de hermenêutica dos textos pesquisados que pressupõe o diálogo entre o pesquisador e seus testemunhos, a sugerir que os relatos de experiências vividas respondam às indagações do presente, sem que isso signifique esvaziar o passado de sua dimensão única e historicamente datada. Esse envolvimento é próprio do conhecimento histórico, ao não se desvencilhar das inúmeras mediações culturais que se interpõem entre o historiador e seu objeto e as interações e influências mútuas envolvidas. Essa abordagem, portanto, consiste em apreender significados e compor um quadro narrativo que conjuga os horizontes de expectativa: "é preciso lutar contra a tendência a se considerar o passado do ponto de vista do acabado, do imutável, do irretocável" (RICOEUR, 1997, p.: 372). Com a Folha de São Paulo é possível acessar os fios da construção de uma memória histórica, no momento de sua produção, algo que foi parte importante da sustentação do regime ditatorial, mas também da construção de trajetórias ligadas ao que seria a chamada transição. O jornal apresenta indícios da elaboração de um horizonte político para o país em meio às relações de poder e disputas eleitorais. Cada notícia, coluna, crônica, anúncio ou nota "não se constitui em um objeto único e isolado" (LUCA, 2005, p. 113), mas ganha sentido como parte de um ciclo narrativo.

Alcançar uma visão diacrônica do processo de construção de diversas representações sociais que serviram como condutoras e legitimadoras de práticas sociais e projetos políticos, bem como de definição dos interlocutores do processo de redemocratização e de seus alcances e limites, depende de atos interpretativos como parte fundamental da operação historiográfica para realizar o trabalho "de compreender o todo a partir do individual e o individual a partir do todo" num "movimento circular", como aponta Hans-Georg Gadamer (1997, p. 436-444). A interpretação pressupõe uma antecipação de sentido, na medida em que intérprete procura partilhar os significados de um texto com seu autor: "quem quer compreender está vinculado com a coisa em questão que se expressa na transmissão", embora não haja um vínculo contínuo e direto com o texto, como uma "unidade inquestionável”. Isso implica em que "existe realmente uma polaridade entre familiaridade e estranheza" e é nesta intermediação que emergem 

surgimento constante de "novas fontes de compreensão que tornam patentes relações de sentido insuspeitadas".

Ao longo do período iniciado com a imposição da ditadura em 1964, o país vivenciou um intenso processo de urbanização, a formação de grandes contingentes de camadas médias urbanas e a estruturação de modernas estruturas de comunicação de massa tiveram efeitos políticos duradouros e profundos na organização da sociedade. A imprensa fez parte do processo de constituição de memórias e foi agente político notável do Brasil contemporâneo. A modernização técnica que se acelerou justamente nos anos da ditadura militar compreendeu uma mais intensa influência na política de massas e nos jogos de poder de então. A elaboração de uma memória histórica do período, encontrada nas páginas do jornal, suscita outro elemento indispensável para a discussão: o público leitor e consumidor de jornais e revistas, formado pelas camadas médias urbanas, importante segmento social de sustentação do regime, principalmente durante o chamado "milagre econômico", que garantiu a formação de um grande mercado de consumo.

Durante todo o período, principalmente o público de classe média foi alcançado pela propaganda política do regime, a qual esteve amparada na afirmação do otimismo como característica inerente ao povo brasileiro (FICO, 1997, p. 137). A linguagem oficial associou a unidade do país a uma suposta postura da população brasileira caracterizada pela esperança e a crença no futuro, algo que estaria inscrito na cultura nacional. $O$ “milagre econômico" e a vitória na Copa do Mundo de 1970 seriam a confirmação do “destino de grandeza do país" e as certezas em relação ao porvir de cada brasileiro. Preocupado com a imagem pública do regime, a política de comunicação estabelecida no governo Médici continuaria com Geisel, inclusive com a manutenção do personagem "Sujismundo", entendido com uma campanha educativa, com o mote "povo desenvolvido é povo limpo", além de "filmetes sobre os temas segurança e desenvolvimento, eleições, confraternização mundial e, também, uma campanha contra 
o desperdício" (FOLHA DE SÃO PAULO, 01/06/1974, p. 1). Verifica-se, assim, que a temática eleitoral entrava nas preocupações dos que atuavam na área de comunicação do governo.

O ambiente socioeconômico começava a desfavorecer o regime e a reduzir as expectativas otimistas quanto ao desempenho do país: a crise do petróleo sugeria expectativas cautelosas. Apesar disso, no início de 1974, o Ministro da Fazenda, Delfim Neto, afiançava a um grupo de banqueiros que, ao contrário do que afirmavam "os profetas do Apocalipse", o problema do petróleo seria "passageiro" e o país começaria a gerar condições para a distribuição de renda, pois a "escassez de mão de obra" impactaria no aumento dos salários, algo que nem os sindicatos, nem o governo conseguiriam realizar, num processo que daria condições ao Brasil para tornar-se "uma sociedade politicamente aberta", compatível com a "descentralização do poder econômico" (FOLHA DE SÃO PAULO, 30/01/1974, p. 1). No final do ano, a Fundação Getúlio Vargas estimava que o crescimento da economia teria sido de cerca de $10 \%$, o que levou o Ministro do Planejamento João Paulo dos Reis Veloso a assegurar a "viabilidade do II Plano Nacional de Desenvolvimento" e a manutenção de "altas taxas de crescimento" (FOLHA DE SÃO PAULO, 27/12/1974, p. 1).

No plano internacional, em meados de 1974 o noticiário também trouxe à tona a questão da democracia. A "Revolução dos Cravos" pôs fim à ditadura salazarista em Portugal e o "vento democrático" de Lisboa soprava nas páginas do jornal brasileiro. As notícias da queda de Marcelo Caetano e o papel das Forças Armadas portuguesas no processo faziam referência à polícia política, a presos políticos e partidos proscritos, assuntos que não ocupavam o noticiário nacional (FOLHA DE SÃO PAULO, 27/04/1974, p. 1).

Enquanto isso, o MDB preparava-se para as eleições de Novembro em uma situação anunciada como frágil, devido à "falta de uma estrutura partidária". O partido vivia problemas inclusive de ordem geracional: os dirigentes mais importantes estavam na faixa etária dos 60 anos e eram oriundos do antigo PSD (Partido Social Democrático), ou seja, "em outros tempos eram governo e não oposição", o que os tornava inábeis para o momento em que viviam. Essa "uniformidade de origem" era deplorada pelo chamado 
um regime autoritário, nas páginas do jornal o debate político encontrava espaço e os temas que envolviam o processo eleitoral ganhavam importância, tanto para o governo, cioso em granjear legitimidade para a ditadura, quanto para a própria oposição, que passava a ver nos mecanismos possibilitados pelo regime uma das poucas alternativas para disputar a opinião popular. O Deputado Federal Alceu Colares chegou a sugerir que ambos os partidos abrissem oficialmente a campanha eleitoral com "uma apresentação conjunta na televisão" de modo a "motivar o eleitorado" e debater abertamente o “modelo econômico brasileiro e suas implicações no plano social” (FOLHA DE SÃO PAULO, 14/08/1974, p. 4).

Nas eleições de 15 Novembro, o partido da oposição obteria "surpreendente e expressiva votação" (FOLHA DE SÃO PAULO, 17/11/1974, p. 1). Logo em seguida, o governo não deixou de ameaçar: acatava o resultado, mas não admitia que "a livre manifestação da vontade popular" fosse "desvirtuada para fins de contestação ao regime". As bases autoritárias da ditadura não deveriam ser questionadas. Ao citar uma fonte palaciana, o jornal reproduziu a seguinte declaração: "não se diga que o povo votou contra o ato institucional, porque isso não é verdade; votou sim contra o custo de vida, o alto preço dos gêneros alimentícios e outras consequências do processo inflacionário" (FOLHA DE SÃO PAULO, 19/11/1974, p. 3).

Sabe-se também que boa parte dos que se envolveram diretamente na oposição ao regime militar, tanto por vínculos familiares quanto ocupacionais, podem ser posicionados na condição de membros da classe média urbana brasileira. Se entre a decretação do Ato Institucional Número 5 (Al-5), em 1968, e os primeiro indícios de fissura no aparato autoritário, em 1974, a discussão política esteve interditada e restrita ao âmbito privado, a partir de então a crítica pública ao regime ampliou-se, mas não sob uma ótica revolucionária ou insurrecional: "a democracia passa a ser valorizada como um objeto em si e, com ela, a organização da sociedade e a participação no jogo eleitoral, mesmo sob limitações" (ALMEIDA; WEISS, 1998, p. 336). 
Esta percepção decorreu, em grande parte, das derrotas sofridas por parte da esquerda que se dedicou à ação direta por meio, principalmente, da luta armada. Se o golpe de 1964 derrubou estratégias voltadas para a conscientização popular e seu engajamento em movimentos nacional-democráticos, a falência das organizações clandestinas envolvidas na revolução armada provocou uma reavaliação da ação política necessária para derrotar o regime e pôs em cena a participação nas disputas eleitorais. A crise das ideias em torno de um certo vanguardismo dos militantes foi evidenciada pelo isolamento social e político das organizações, o que facilitou a repressão por parte da ditadura. No início da década de 1970, “cercadas nas cidades, e, nas cidades, cercadas, as organizações revolucionárias agonizavam”. Marcelo Ayres Camurça e Daniel Aarão Reis (2007, p. 137-138) focalizam o caso do Movimento Revolucionário 8 de Outubro (MR-8) e demonstram que a autocrítica levou a grande parte dos integrantes a "encerrar a luta e as ações armadas e iniciar no Brasil um trabalho de massas nos sindicatos operários e nas associações populares". Em 1974, houve ativa participação no processo eleitoral, junto ao MDB, o que se aprofundou a partir de então, com a transformação da organização em uma entidade mobilizadora vinculada ao partido e a algumas de suas lideranças proeminentes, principalmente em períodos eleitorais.

\section{A narrativa da democratização}

As eleições e a valorização do voto introduziram elementos novos na cultura política brasileira, até então marcada pela desqualificação de mecanismos institucionais de participação popular e de imagens ressentidas forjadas na crença elitista sobre um suposto despreparo da população para o voto (BENEVIDES, 1994, p. 5-17). Em 1976, a Folha de São Paulo opinava: "pregou-se durante muito tempo que o desenvolvimento do País era uma das precondições para a implantação da plenitude democrática em terras brasileiras", mas com a inviabilidade do crescimento econômico sem "avanços também nos setores político e social", o comportamento do Estado deveria ser alterado. Isso implicaria em perceber que o País "estava maduro para aberturas políticas, vale dizer, sobretudo, mais poderes aos civis nas decisões nacionais" (FOLHA DE SÃO PAULO, 03/01/1976, p. 2). 
As eleições canalizaram as diversas formas de mobilização social para as disputas partidárias formais e a imprensa apareceu como mediadora das diversas vozes e, na condição de testemunha privilegiada, investiu-se do papel de construtora da memória histórica da democratização. Empresas jornalísticas que, até então, haviam tido uma participação ambígua no processo político brasileiro, como a própria Folha de São Paulo, inclusive com apoio registrado à implantação e sustentação do regime, avocaram uma posição de destaque nas tramas e conflitos que envolveram a democratização do sistema político brasileiro e nomearam os interlocutores que deveriam conduzir o país à democracia política. O apoio à campanha pelas Diretas garantiria à Folha de São Paulo "a possibilidade de elaborar para si outra narrativa de sua participação na história recente do país; em pouco tempo, esses episódios se tornam o principal foco na tessitura da memória, fazendo com que parte do passado perca importância na formação do novo papel social que se propõe exercer" (SILVA, 2011, p. 190).

Diante disso, a partir de meados da década de 1970, boa parte da imprensa escrita aparece não apenas como espectadora, mas como interlocutora importante, nas questões políticas que envolveram a chamada "distensão", a posterior abertura "lenta, gradual e segura” e a constituição da “Nova República”. Esses três momentos históricos, configurados nos governos de Ernesto Geisel, João Figueiredo e José Sarney, foram amplamente cobertos, inicialmente com as dificuldades devidas ao controle de informações e à censura prévia (bem como à autocensura, deve-se lembrar), pelos jornais brasileiros, os quais viveram um momento de uma paradoxal modernização tecnológica e editorial em meio a um regime autoritário. As páginas dos jornais, aos poucos, constituíram-se em veículos para as representações sociais e políticas do país como um todo, a ponto de setores da imprensa situarem-se como peças indispensáveis da construção democrática brasileira. Por ocasião da passagem do vigésimo aniversário do golpe de 1964, o Editorial da Folha de São Paulo apresentou um balanço daquele ciclo histórico, num momento em que se exigia "a busca de caminhos novos que conduzam realmente a uma democracia moderna e sólida, e uma economia capaz de liquidar os bolsões de miséria, os extremados desequilíbrios regionais e sociais", o que pressuporia "a separação definitiva das regras autoritárias que presidiram esta fase do processo 
O tempo é uma experiência social que preside trajetórias individuais e coletivas. Para Krysztof Pomian (1993, p. 104-105) o tempo linear coexiste com a temporalidade cíclica por meio de práticas como a adivinhação, os planos e os prognósticos, nas quais são identificadas coordenadas sociais que inscrevem o futuro no presente. Atribuir ao presente a posição de marco inicial de um período ascendente, como uma progressão, torna o futuro o "objeto duma esperança, ao passo que o passado é concebido não como aquilo que fornece exemplos a seguir, mas como um período decorrido". Ao contrário, quando o presente é tomado como regressão, o futuro torna-se depositário de angústias e "voltamo-nos para o passado a fim de imitá-lo na medida do possível". Ao longo do século $\mathrm{XX}$, o tempo histórico deixou de ser tomado como um "fluir uniforme" e preestabelecido, o que dotou de relevância a observação dos processos sociais, de modo a compreender suas singularidades, variações e ritmos próprios, em períodos curtos ou longos, na forma de modelos que estabelecem uma "sucessão de ciclos, de períodos de desenvolvimento, de declínio, de estagnação, de recomeço" (POMIAN, 1993, p. 154-160).

Uma das características do papel exercido pelo jornal nesse processo foi sua decisiva contribuição no sentido de fixar marcos de narrativas que concertaram ações e ordenaram interpretações acerca do ciclo histórico iniciado em 1974. A partir de então, é possível identificar a constituição de uma fase ascendente de um ciclo temporal e narrativo que organizaria os movimentos dos agentes políticos para a propalada redemocratização. Governo e oposição formavam consensos e encaminhavam um lento consenso sobre o futuro a ser trilhado, com a legitimidade assegurada pela imprensa, apresentada como portadora de elementos considerados fundamentais para uma cultura política democrática, como a liberdade de expressão e a defesa da opinião pública. Ulysses Guimarães afirmou, em 1978, voltou a pontuar necessidade da anistia: “não basta arrastar-se timidamente, no rumo dos acontecimentos; é preciso antecipar-se a eles. Basta realizar a anistia para que o país retome o diálogo" (FOLHA DE SÃO PAULO, 01/07/1978, p. 4). Na constituição desses marcos de referência do ciclo narrativo, foi 
Apontar para a problemática da relação com o Estado, o autoritarismo, a censura, a elaboração de representações culturais que se tornam predominantes e práticas de poder que atuam nas disputas e acertos políticos. No caso do jornal Folha de São Paulo, percebe-se sua apresentação como anteparo para a elaboração de uma memória histórica do processo de democratização que tendeu a legitimar posições e sublimar possibilidades. Em 1979, ao avaliar a necessidade da anistia, um Editorial estabeleceu as balizas orientadoras do processo. Com o retorno dos exilados, o país voltava "ao clima que precede a reconciliação de que necessita para cicatrizar todas as chagas do arbítrio, como as feridas da violência política" e prosseguir com a "distensão dirigida" (FOLHA DE SÃO PAULO, 04/01/1979, p. 2) com a qual governo, oposição e imprensa estavam comprometidos.

Em Agosto de 1979 foi promulgada a Lei de Anistia, apresentada como "ampla, geral e irrestrita", com a qual o governo procurou controlar e esvaziar a campanha nacional lançada como Comitê Brasileiro pela Anistia, criado um ano antes e que congregava entidades que atuavam há anos na luta pelos direitos humanos e na defesa dos presos políticos. A legislação garantiria a impunidade para os perpetradores da ditadura, particularmente para aqueles mais diretamente comprometidos com o aparato repressivo. Para Carlos Fico, “as etapas do processo de 'abertura' foram planejadas para atender ao ritmo cauteloso estabelecido por Ernesto Geisel” (FICO, 2010). Com a nova lei, retornaram ao país os políticos e ativistas que partiram para o exílio por não verem condições de sobreviver sob as condições da ditadura, entre os quais o trabalhista Leonel Brizola e o comunista Luís Carlos Prestes.

As expectativas sociais e a dispersão de propostas encontrariam um momento privilegiado de condensação durante as discussões que redundaram na instauração da chamada Nova República. Para Marcos Napolitano (2002, p. 145-162), "a 'linguagem dos direitos' parece ter norteado o discurso jornalístico do período, em que pese os diversos matizes ideológicos". O engajamento na "questão democrática", que circulava com 

plenamente atingido".

Apesar da pluralidade de culturas políticas e de sentidos atribuídos à redemocratização, na narrativa que a Folha de São Paulo ajudou a construir, o processo histórico deveria conduzir para uma democracia baseada na delegação de poder popular aos núcleos políticos e partidários formais que se consolidaram desde 1974, os quais dispunham da legitimidade para manifestar-se em nome da população e garantir um rumo estável ao processo de abertura. Vale lembrar que, desde o fim do governo de Ernesto Geisel, em 1979, as lideranças do regime autoritário começaram a dar sinais no sentido de que a volta da democracia era algo que estava posto no horizonte. Para este processo se efetivar seria preciso remover os entulhos autoritários do sistema político, todavia, conforme preconizavam os governantes, de forma lenta e gradual. Decorreram aproximadamente 10 anos para que uma possível democracia se tornasse uma realidade nas diferentes esferas da sociedade brasileira, sendo que estas relações foram pautadas, sobretudo, na Carta Magna de 1988. Almejava-se na época que as chamadas legislações complementares fossem formuladas sob este mesmo prisma.

A Folha foi um dos órgãos da grande imprensa que configurou a narrativa que dotou de sentido histórico os eventos e personagens mais destacados do processo de abertura política, ao mesmo tempo em que assegurava a posição de elemento indispensável ao jogo democrático brasileiro. A imprensa é parte do campo político, como um dos agentes a influir sobre as tomadas de posição, por apresentar possibilidades estratégicas submetidas "à escolha dos agentes". Entende-se então que "os partidos, como as tendências no seio dos partidos, só têm existência relacional" e dependem da estrutura de negociações e transações estabelecidas entre adversários e aliados, com base em um repertório comum visibilizado nas páginas de jornais e revistas no processo de democratização (BOURDIEU, 1989, p.178). A impossibilidade das eleições diretas para a Presidência da República conduziu aos acordos que permitiriam a eleição de um civil conforme as regras e condições negociadas com o regime autoritário. A eleição de 
Tancredo Neves pelo Colégio Eleitoral foi então apresentada como fim do ciclo autoritário, mas ao mesmo tempo parte indispensável do ciclo da redemocratização: “esta reunião do colégio eleitoral (...) assume grande significado simbólico, pois marca o fim de todo um período da História do país. Sua importância reside assim conforme anseia a Nação, precisamente em ser a última" (FOLHA DE SÃO PAULO, 15/01/1985, p. 2). Em continuação, no dia seguinte à vitória, o jornal vaticinou: "a eleição de Tancredo para Presidência da República marcou o fim de um ciclo na vida política brasileira". E avançou na definição dos significados daquele marco: o autoritarismo configurara "o contumaz desrespeito à opinião pública, à memória dos cidadãos, o descompromisso com qualquer ideia da qual não se possa tirar imediata vantagem pessoal, o uso sistemático da desinformação e do desrespeito" (FOLHA DE SÃO PAULO, 16/01/1985, p. 2), práticas condenadas e substituídas pela esperança na democracia.

A imprensa é fonte indispensável para compreender um passado presente, não como algo estável e congelado, mas como suportes de uma memória intencionalmente produzida, ao instaurar sentidos e legitimar determinados processos políticos. Neste caso, um jornal como a Folha de São Paulo foi um dos mediadores de lembranças, posto que, em certa medida, "é pelo discurso de terceiros que os sujeitos são informados sobre o resto dos fatos contemporâneos a eles", por meio de construções baseadas em fontes “crescentemente midiáticas” (SARLO, 2007, p. 90-92) e que influenciaram as percepções e lembranças de um período de tempo recente, com impactos tanto nas trajetórias individuais quanto em experiências coletivas. Segundo Jacques Le Goff (1994, p. 142-143) a inteligibilidade das tramas e tessituras que envolveram a construção de eventos e fatos alçados ao estatuto de "acontecimentos históricos" envolveu a intervenção dos veículos de comunicação de massa. A memória social passa a ser composta pelo "discurso da informação", que apresenta a sucessão de acontecimentos narrados na imprensa como parte de uma história vivida, imediatamente memorizada e escrita. Não se trata apenas de registro, mas de participação na construção social dos eventos. A narrativa política aparece então na forma de textos jornalísticos construídos como nós de articulação entre veículos, movimentos e atores sociais. Com sua intervenção, foram atribuídos sentidos e fixadas explicações referidas às culturas políticas, entendidas como redes de percepções 
e experiências sociais. Estas grades de leitura do social atuaram tanto no âmbito de relações capilares e microssociais como nos fenômenos históricos abrangentes, ao formar conjuntos de crenças e símbolos, regras e práticas que, combinados, prefiguraram as negociações politicas envolvidas na redemocratização.

\section{Referências}

ABREU, Alzira Alves de; LATTMAN-WELTMAN, Fernando. Uma instituição ausente nos estudos de transição: a mídia brasileira. In: ABREU (Org.) A democratização no Brasil: atores e contextos. Rio de Janeiro, Editora FGV: 2006. p. 67-93.

ALMEIDA, Maria Hermínia T. de; WEIS, Luiz. Carro-zero e pau-de-arara: o cotidiano da oposição de classe média ao regime militar. In: SCHWARCZ, Lilia Moritz (Org.) História da vida privada no Brasil, 4: contrastes da intimidade contemporânea. São Paulo: Cia das Letras, 1998. p. 319-410.

AVRITZER, Leonardo. Cultura política, atores sociais e democratização: uma crítica das teorias da transição para a democracia. Revista Brasileira de Ciências Sociais, Belo Horizonte, MG, v. 10, n.28, 1995. Disponível em <http://www.anpocs.org.br/portal/publicacoes/rbcs_00_28/rbcs28_09.htm>, acesso em 23 Out. 20013.

BARTHES, Roland. O efeito de real. In: GENETTE, Gérard et al. Literatura e semiologia: pesquisas semiológicas. Petrópolis: Vozes: 1972. p. 35-44.

BENEVIDES, Maria Victoria de Mesquita. Cidadania e democracia. Revista Lua Nova. 1994, n.33, p. 5-16.

BERNSTEIN, Serge. A cultura política. In: RIOUX, Jean-Pierre; SIRINELLI, Jean-François (orgs.). Para uma história cultural. Lisboa: Estampa, 1998. p. 349-363.

BIROLI, Flávia. Representações do golpe de 1964 e da ditadura na mídia: sentidos e silenciamentos na atribuição de papéis à imprensa, 1984-2004. Varia História. 2009, v.25, n.41, p. 269-291.

BOURDIEU, Pierre. O poder simbólico. Lisboa: Difel; Rio de Janeiro: Bertrand, 1989. 
CAMURÇA, Marcelo Ayres; REIS, Daniel Aarão. O Movimento Revolucionário 8 de Outubro (MR-8). Da luta armada contra a ditadura à luta eleitoral no PMDB. In: FERREIRA, Jorge; REIS, Daniel Aarão (orgs.). Revolução e democracia (1964-...). Rio de Janeiro: Civilização Brasileira, 2007. p. 131-148.

CASTRO, Celso; D’ARAÚJO, Maria Celina (Orgs.). Dossiê Geisel. Rio de Janeiro: Editora FGV, 2002.

CODATO, Adriano Nervo. Uma história política da transição brasileira: da ditadura militar à democracia. Revista de Sociologia Política. 2005, n.25, p. 83-106.

D’ARAÚ JO, Maria Celina; CASTRO, Celso (Orgs.). Ernesto Geisel. Rio de Janeiro: Fundação Getúlio Vargas, 1997.

FERREIRA, Lucia Maria Alves. Uma memória da normatização da conduta feminina na imprensa. In: RIBEIRO, Ana Paula Goulart; FERREIRA, Lucia Maria Alves.. (Org.). Mídia e memória: a produção de sentidos nos meios de comunicação. 1. ed. Rio de Janeiro: Mauad X, 2007, v. 1, p. 57-71.

FICO, Carlos. Reinventando o otimismo: ditadura, propaganda e imaginário social no Brasil. Rio de Janeiro: Ed. FGV, 1997.

FICO, Carlos. A negociação parlamentar da anistia de 1979 e o chamado "perdão aos torturadores". Revista Anistia Política e Justiça de Transição, Brasília: Ministério da Justiça, n.4, jul./dez. 2010, p.318-333.

FOLHA DE SÃO PAULO. São Paulo: Folha da Manhã, 1960 a 1988

GADAMER, Hans-Georg. Verdade e método: traços fundamentais de uma hermenêutica filosófica. Petrópolis: Vozes, 1997.

GRINBERG, Lúcia. Partido político ou bode expiatório: um estudo sobre a Aliança Renovadora Nacional (ARENA), 1965-1979. Rio de Janeiro: Mauad X, 2009.

KOSELLECK, Reinhart. Futuro passado: contribuição à semântica dos tempos históricos. Rio de Janeiro: Contraponto; PUC-Rio, 2006.

KUSHNIR, Beatriz. Cães de guarda: jJornalistas e censores - do Al-5 à constituição de 1988. São Paulo: Boitempo, 2004.

LAMOUNIER O Brasil autoritário revisitado: o impacto das eleições sobre a abertura. In: STEPAN, Alfred (Org.). Democratizando o Brasil. Rio de Janeiro: Paz e Terra, 1988. p. 83134. 
LE GOFF, Jacques. História e memória. Campinas: Ed. Unicamp, 1994.

LUCA, Tânia Regina de. A história dos, nos e por meio dos periódicos. In: PINSKY, Carla Bassanezi (Org.). Fontes históricas. São Paulo: Contexto, 2005. p. 111-153.

MOTA, Carlos Guilherme; CAPELATO, Maria Helena. História da Folha de São Paulo: 19211981. São Paulo: Impres, 1981.

NAPOLITANO, Marcos. Cultura e poder no Brasil contemporâneo. Curitiba: Juruá, 2002.

NORA, Pierre. O retorno do fato. In: LE GOFF, Jacques; NORA, Pierre. História: novos problemas. Rio de Janeiro: Francisco Alves, 1988. p. 179-193.

PILATTI, Adriano. A Constituinte de 1987-1988: progressistas, conservadores, ordem econômica e regras do jogo. Rio de Janeiro: Lumen Juris, 2008.

PEREIRA, Mateus Henrique de Faria. A máquina da memória: o tempo presente entre a história e o jornalismo. Bauru: Edusc, 2009.

POMIAN, Kryzstof. Ciclo. In: ROMANO, Ruggiero. (Dir.) Enciclopédia Einaudi. Tempo/temporalidade. Lisboa: Imprensa Nacional, vol. 29, 1993.

PRADO, Luiz C. Delorme; EARP, Fábio Sá. O “milagre” brasileiro: crescimento acelerado, integração nacional e concentração de renda. In: FERREIRA, Jorge; DELGADO, Lucília de A. Neves (Orgs.). O Brasil republicano, 4: o tempo da ditadura. Regime militar e movimentos sociais em fins do século XX. Rio de Janeiro: Civilização Brasileira: 2003.p. 207-242.

RIBEIRO, Ana Paula Goulart. Modernização e concentração: a imprensa carioca nos 19501970. In: NEVES, Lúcia Maria B. P. et al (Orgs.). História e imprensa: representações culturais e práticas de poder. RJ: DP\&A; FAPERJ, 2006. p. 426-435.

RICOEUR, Paul. A memória, a história, o esquecimento. Campinas: Ed. Unicamp, 2007.

RICOEUR, Paul. Tempo e narrativa: tomo I. Campinas: Papirus, 1994.

RICOEUR, Paul. Tempo e narrativa. tomo III. Campinas: Papirus, 1997.

ROSANVALLON, Pierre. Por uma história conceitual do político. Revista Brasileira de História, v. 15, n. 30, p. 9-22, 1995. 
RÜSEN, Jörn. Razão histórica: teoria da história: fundamentos da ciência histórica. Brasília: UNB, 2001.

SARLO, Beatriz. Tempo passado: cultura da memória e guinada subjetiva. São Paulo: Cia das Letras, 2007.

SILVA, Sonia Maria de Meneses. A operação midiográfica: a produção de acontecimentos e conhecimentos históricos através dos meios de comunicação - a Folha de São Paulo e o Golpe de 1964. Tese (Doutorado). Universidade Federal Fluminense, Instituto de Ciências Humanas e Filosofia. Departamento de História, 2011.

TODOROV, Tzvetan. As estruturas narrativas. São Paulo: Perspectiva, 1970.

Recebido em: 31/10/2013 Aprovado em: 28/11/2013

Universidade do Estado de Santa Catarina - UDESC Programa de Pós-Graduação em História - PPGH

Revista Tempo e Argumento Volume 05 - Número 10 - Ano 2013 tempoeargumento@gmail.com 